\title{
新規産業の成長々産業構造展望
}

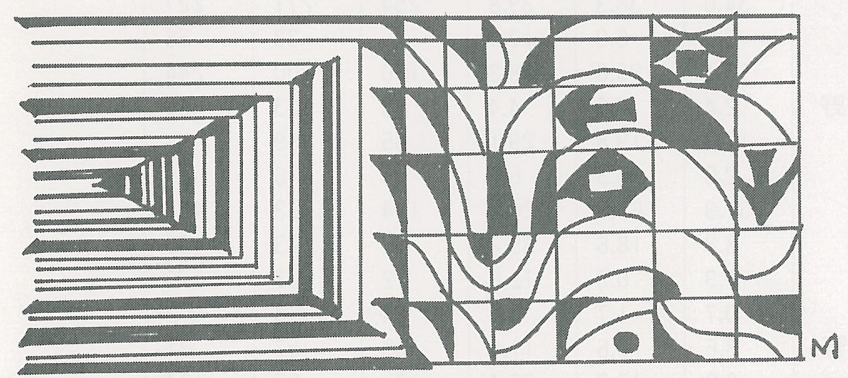

\section{吉野 潤}

(資源エネルギー庁)

‘94年6月に通商産業大臣の諮問機関である産業構造審議会の総合部会基本問題小委員会 (小委員長：辻村江太郎総合部会長)において, 我が国の中長期の産業構造の展望を行うとと もに,21 世紀の蓙業構造を実現するたかの新たなパラダイムに立脚した産業政策を提示した報 告書がとりまとめられた。本報告畫は, 同小委員会の中に設置された産業構造検討特別委員会 (委員長：香西泰日本経済研究セン夕一理事長)での検討をベースとしたものである。 本報告書は以下の現状認識に基づいて検討され,取りまとめられたものである。本稿において は，弚の概要と産業構造の展望作業を中心に報告することとしたい。”

\section{1.はじめに}

我が国経済は，既にキャッチアップの時代を 終え，フロントランナーの一員として，来るべ き 21 世紀に向けて，自ら新たなフロンティア を切り開いていくべき時期にある。世界経済と の関係についてみると, いわゆるグローバル 化・ボーダーレス化が一段と進展する中で，ア ジアにおける工業化水準の急速な向上, 東欧諸 国の市場経済化の進展, いわゆる米国製造業の 「復活」等によりダイナミックな国際競争の時代 に突入しており，我が国産業の国際競争力の相 対的な低下が急速に進むことが憂慮されてい る。

このような状況の下, 我が国産業構造は, 既 存産業の成熟化・新規産業の展開の遅れ, 製造 業の海外展開の加速と産業の空洞化の㴽念, 本 格的なりストラの進展に伴う雇用不安等, 大き な曲がり角にある。特に, オイルショック以降 一貫して，我が国経済を呼引する大きな力とな
つてきた自動車・電機に代表される機械産業及 びそのすそ野産業が, 国内需要の成熟化や生産 の海外展開に伴い，これまでの延長線上ではそ の将来をとらえにくくなってきている一方で, 次代を担う新規・成長産業が十分に見えないこ とが現在における閉塞感, 将来に対する不透明 感を高めている。

このような状況の下，消費者や企業のマイン ドは悲観的な方向にブレがちとなっており, 政 府は適切なマクロ経済運営を行うとともに一定 の政策を採ることを前提として，市場メカニズ ムが適切に機能するとすればいかなる産業構造 が実現しうるかを1つの情報として提示するこ とにより，不透明感を払拭することが求められ ている。

また，これまでの我が国経済構造全体の行き 詰まりが顕在化するなか, 経済構造改革を推進 する一環として，21 世紀の産業構造の実現に 向けて, 新たなパラダイムに立脚した産業政策 が求められている。 


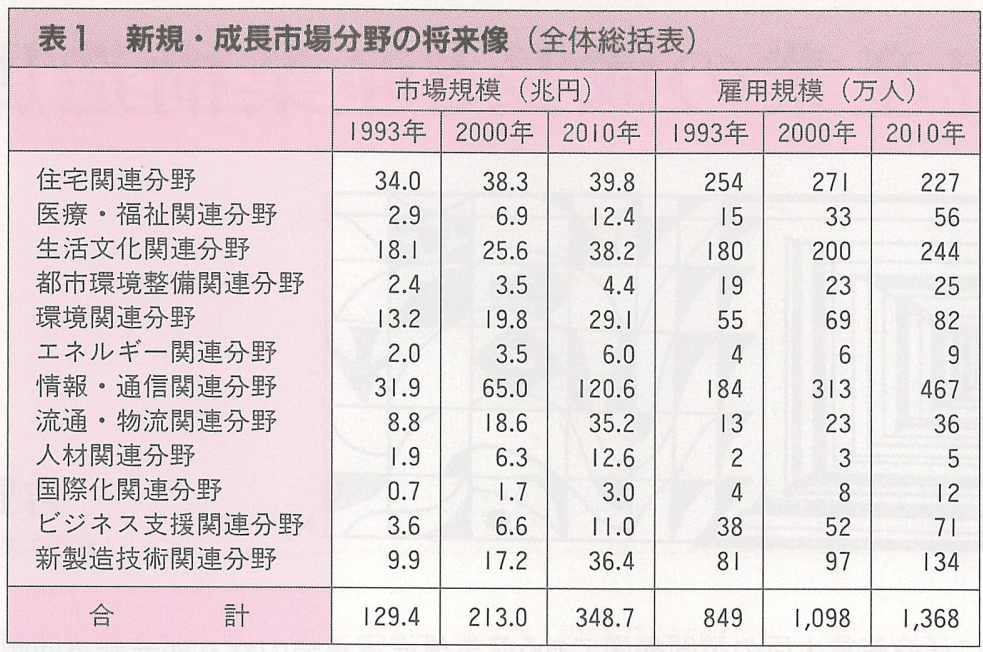

\section{2. 報告書の概要}

\section{（1）中長期的な産業構造の展望}

\section{2000 年, 2010 年の産業構造・就業構造}

（1）新規・成長市場群の将来展望 (表 1)

住宅関連分野, 医療・福祉関連分野, 環境関 連分野, 情報・通信関連分野等今後の成長が期 待される社会ニーズ対応型の 12 の新規・成長市 場群の市場 (需要) 規模の展望を行った。合計で 現在の約 130 兆円が, 2000 年 210 兆円程度 (1993 年に比べ, 80 兆円程度の増加)，2010 年 350 兆円程度 (2000 年に比べ,さらに 140 兆円 程度の増加）に拡大すると見込まれる。これに 対応する就業者数は, 現在の約 850 万人が, 2000 年 1,100 万人程度 (1993 年に比べ, 250 万 人程度の增加), 2010 年 1,370 万人程度 $(2000$ 年に比べ，さらに 270 万人程度の増加）と大き な雇用機会が創出されると見込まれる。

（2）産業構造全体の展望(表 2)

これら新規・成長市場群を産業側からとらえ 直し, かつ他分野も含め, 産業間の相互依存関 係のチェックを行うとともに，エネルギー需給 見通しとの整合性等を図りつつ, 産業構造全体 の展望を行った。特徵としては, 「産業関連サ ービス」(2000 年まで 7.7\%，2010 年まで 5.1 $\%)$ ，「電気・電子機械」 $(3.8 \%, 3.6 \%)$ などが高 い伸びとなる。一方，「輸送機械・産業機械」,
「金属系素材」，「非金属系素材」などのウエイト は低下すると見込まれる。

（3）需要サイドを重視した新産業分類による展 望 (表 3)

業際化等に伴う産業分類の流動化を踏まえ, 産業分類を家計関連，産業関連，両用財・サ一 ビスに大胆に再構成してみると，「生活向上 財・サービス (基礎的消費以外の消費財・サービ ス) $\lrcorner(3.5 \%, 2.7 \%)$ ，「産業基盤財(投資財，基 盤部品)」(6.6\%，4.8\%)が高い伸びを示すと見 込まれる。

(4) 就業構造・職種構成 (表 4，5)

就業構造変化の特徵としては,「産業関連サ 一ビス」、「生活関連サービス」などの増加と「流 通・運輸」などの減少が見込まれ，職種構成の 変化を見ると,「知識・専門的職業従事者」が著 増する一方，企業の間接部門や流通業の合理 化·効率化に伴い「管理的職業従事者」「「販売従 事者」は減少傾向となり，専門化した質の高い 労働力のウエイトが高まると見込まれる。

\section{2 。展望のインプリケーション}

(1)マクロ構造調整，ミクロ経済改革，産業構造 政策を三位一体とした政策が実行されることを 前提とすれば， 2000 年まで $3 \%$ 強・2010 年まで $2 \%$ 台半ばの実質経済成長，労働力需給のバラ ンス, 経常収支黒字縮小下での内需型経済構造 は実現可能と見込まれる。ただし，既存分野の スリム化，新規・成長市場の創造による大規模 


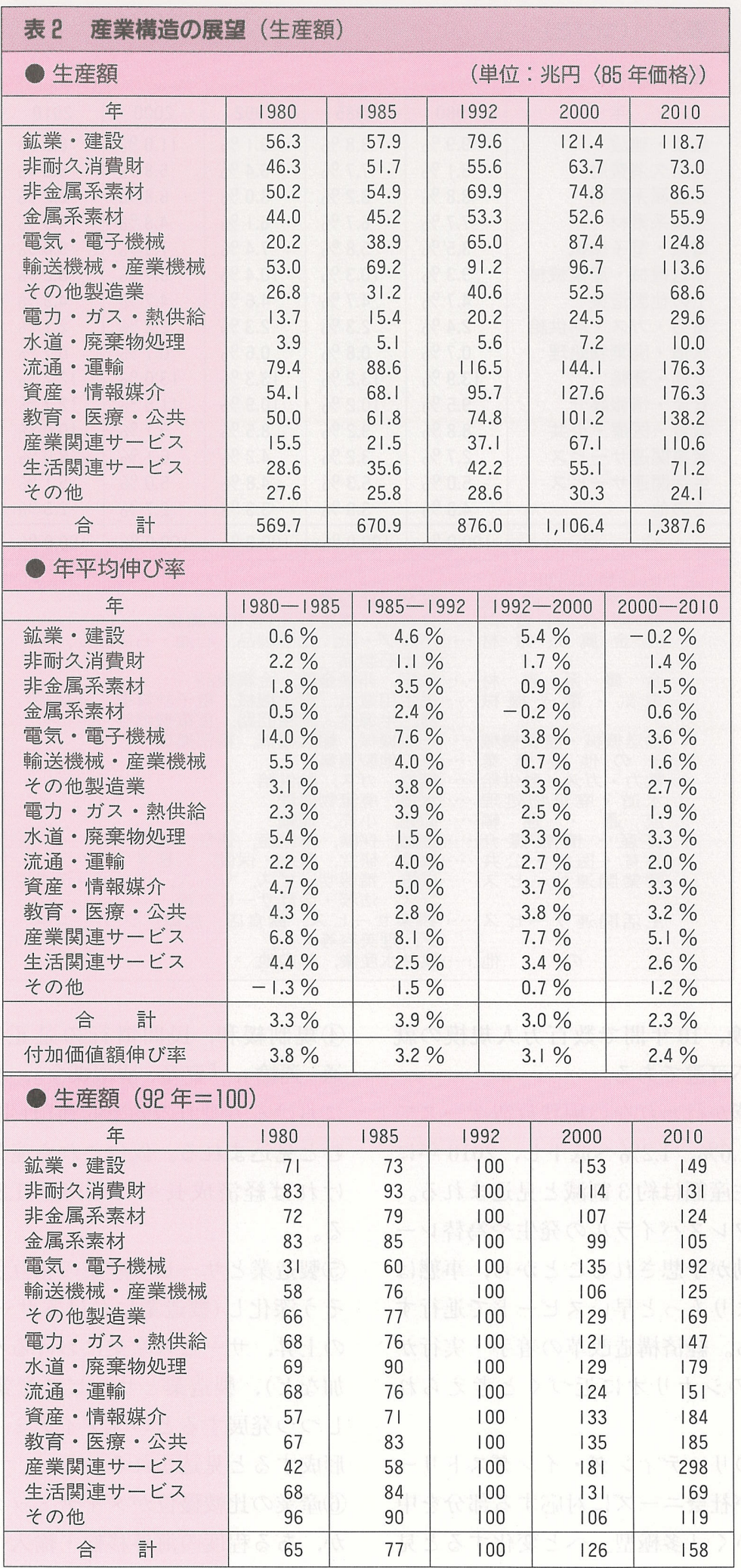




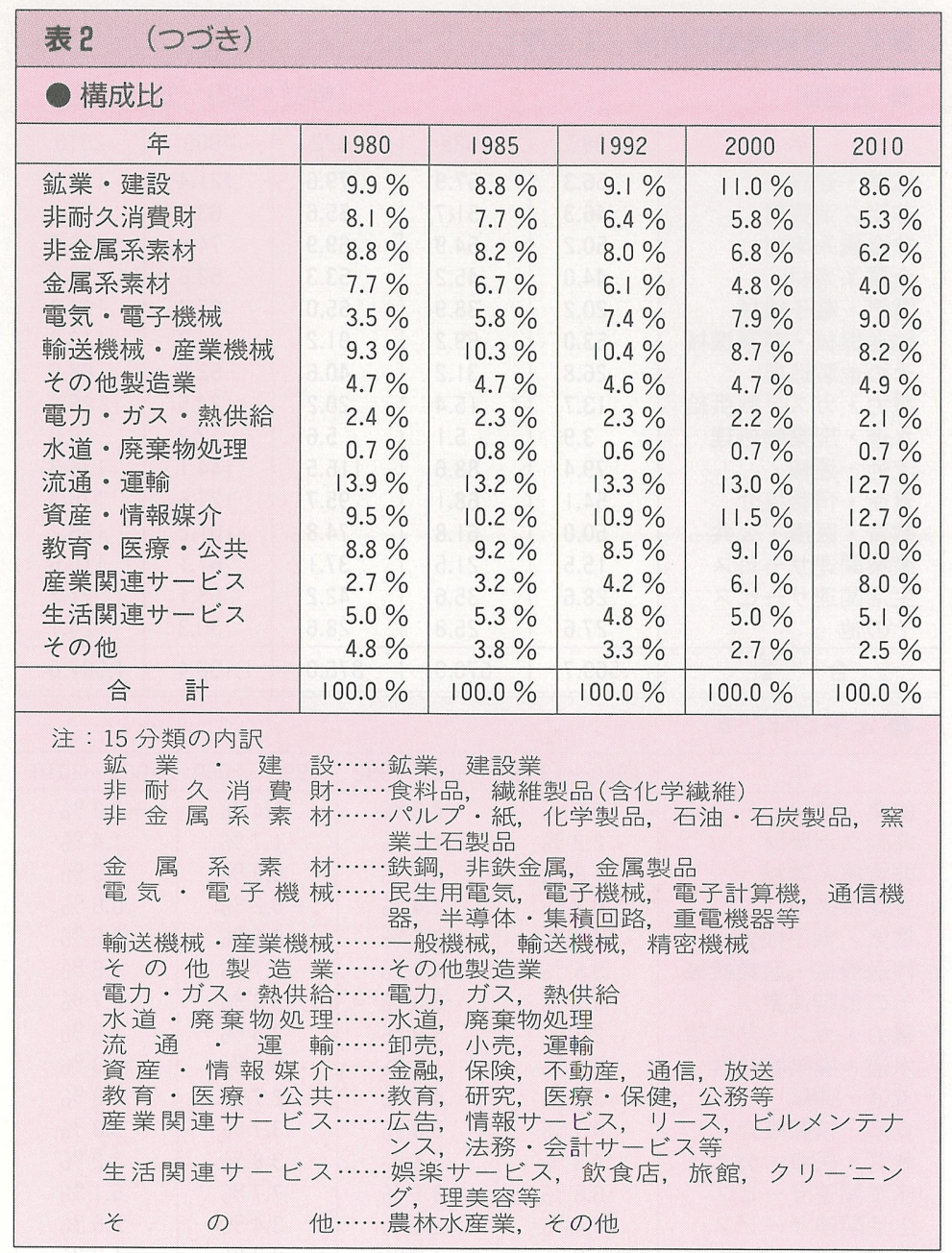

な産業構造転換, 10 年間で数百万人規模の就 業構造転換が不可避である。

(2)経済構造改革が行われない現状放置ケースで は，成長率は $1.6 \% ， 1.2 \%$ へ低下し，2010 年に おける製造業生産額は約 3 割減と見込まれる。 現実には，デフレスパイラルの発生や為替レー トの大きな変動が予想されることから，事態は この試算結果よりもつと早いスピードで進行す る可能性もある。経済構造改革の着手・実行が 遅れるほどこのシナリオに近づくと考えられ る。

(3)一極集中型のリーディング・インダストリー から，各産業が社会ニーズに対応する部分を中 心に発展していく「多極型」へと变化すると見 込まれる。
(4)規制緩和，民間慣行の是正等により，「流 通・運輸」,「資産・情報媒介」, など非効率産業 における労働力の効率的利用 (生産性上昇) が進 むと見込まれる。仮にこれら産業の効率化がな ければ経済成長率は $2.1 \% ， 1.3 \%$ と試算され る。

(5)製造業とサービス産業の相互依存関係がいつ そう深化し(製造業におけるサービス投入比率 の上昇，サービス産業に扔けるハード投資の増 加など), 製造業とサービス産業が相互に連関 しつつ発展するというダイナミックな良循環を 形成すると見込まれる。

(6)産業の比較優位がダイナミックに変化するな か, ある程度の海外移転・輸入への代替は構造 調整そのものであって, グローバルな最適化につ 


\begin{tabular}{|c|c|c|c|c|c|}
\hline \multicolumn{3}{|l|}{ 生産額 } & \multicolumn{3}{|c|}{ (単位：兆円〈85 年価格〉) } \\
\hline \multicolumn{2}{|r|}{ 年 } & 1985 & 1992 & \multirow{2}{*}{\begin{tabular}{|r|}
2000 \\
105.6 \\
226.7 \\
27.7 \\
\end{tabular}} & \multirow{2}{*}{$\begin{array}{r}2010 \\
123.0 \\
294.8 \\
41.0 \\
\end{array}$} \\
\hline $\begin{array}{l}\text { I. 家計関連財・ } \\
\text { サービス }\end{array}$ & $\begin{array}{l}\text { A. 基礎的消費 (衣・食・住) } \\
\text { B. 告活向上消費 } \\
\text { C. 家計投資 (住宅建設) }\end{array}$ & $\begin{array}{r}79.0 \\
141.6 \\
15.6\end{array}$ & $\begin{array}{r}92.2 \\
172.1 \\
20.2\end{array}$ & & \\
\hline $\begin{array}{l}\text { 2. 産業活動関連 } \\
\text { 財・サービス }\end{array}$ & $\begin{array}{l}\text { A. 産業基盤財 } \\
\text { B. 産業活動関連サービス } \\
\text { C. 素材，艺の他 }\end{array}$ & $\begin{array}{r}55.9 \\
33.3 \\
150.3 \\
\end{array}$ & $\begin{array}{r}88.8 \\
54.8 \\
186.3\end{array}$ & $\begin{array}{r}118.0 \\
91.6 \\
193.1\end{array}$ & $\begin{array}{l}167.2 \\
146.0 \\
216.0\end{array}$ \\
\hline $\begin{array}{l}\text { 3. 禹用財・サー } \\
\text { ビス }\end{array}$ & $\begin{array}{l}\text { A. 住宅を除く建設 } \\
\text { B。ネットワークエネー }\end{array}$ & $\begin{array}{l}37.7 \\
157.5\end{array}$ & $\begin{array}{r}53.4 \\
208.1\end{array}$ & $\begin{array}{r}80.1 \\
263.6 \\
\end{array}$ & $\begin{array}{r}60.6 \\
338.9 \\
\end{array}$ \\
\hline \multicolumn{2}{|r|}{ 合計 } & 670.9 & 876.0 & $1,106.4$ & $1,387,6$ \\
\hline \multicolumn{6}{|l|}{ 年平均伸び率 } \\
\hline \multicolumn{2}{|r|}{ 年 } & $1985-1992$ & \multicolumn{2}{|c|}{$1992-2000$} & $2000-2010$ \\
\hline $\begin{array}{l}\text { I. 家計関連財・ } \\
\text { サービス }\end{array}$ & $\begin{array}{l}\text { A. 基礎的消費（衣・食・住） } \\
\text { B. 生活向上消費 } \\
\text { C. 家計投資 (住宅建設) }\end{array}$ & $\begin{array}{l}2.2 \% \\
2.8 \% \\
3.8 \%\end{array}$ & \multicolumn{2}{|c|}{$\begin{array}{l}1.7 \% \\
3.5 \% \\
4.0 \% \\
\end{array}$} & $\begin{array}{l}1.5 \% \\
2.7 \% \\
4.0 \%\end{array}$ \\
\hline $\begin{array}{l}\text { 2. 産業活動関連 } \\
\text { 財・サービス }\end{array}$ & $\begin{array}{l}\text { A. 産業基盤財 } \\
\text { B. 産業活動関連サービス } \\
\text { C. 素材, その他 }\end{array}$ & $\begin{array}{l}6.8 \% \\
7.4 \% \\
3.1 \%\end{array}$ & \multicolumn{2}{|c|}{$\begin{array}{l}3.6 \% \\
6.6 \% \\
0.5 \%\end{array}$} & $\begin{array}{l}3.5 \% \\
4.8 \% \\
1.1 \%\end{array}$ \\
\hline $\begin{array}{l}\text { 3. 両用財・サー } \\
\text { ビス }\end{array}$ & $\begin{array}{l}\text { A. 住宅を除く建設 } \\
\text { B. ネットワークエネルギー }\end{array}$ & $\begin{array}{l}5.1 \% \\
4.1 \%\end{array}$ & \multicolumn{2}{|c|}{$\begin{array}{l}5.2 \% \\
3.0 \%\end{array}$} & $\begin{array}{r}-2.7 \% \\
2.5 \% \\
\end{array}$ \\
\hline \multirow{2}{*}{\multicolumn{2}{|c|}{$\begin{array}{c}\text { 合 計 } \\
\text { 付加価值額伸び率 }\end{array}$}} & $3.9 \%$ & \multicolumn{2}{|c|}{$3.0 \%$} & $2.3 \%$ \\
\hline & & $3.2 \%$ & \multicolumn{2}{|c|}{$3.1 \%$} & $2.4 \%$ \\
\hline \multicolumn{6}{|c|}{ 生産額（92 年=100） } \\
\hline \multicolumn{2}{|c|}{ 年 } & 1985 & 1992 & 2000 & 2010 \\
\hline $\begin{array}{l}\text { 1. 家計関連財・ } \\
\text { サービス }\end{array}$ & $\begin{array}{l}\text { A. 基礎的消費（衣・食・住） } \\
\text { B. 生活向上消費 } \\
\text { C. 家計投資 (住宅建設) }\end{array}$ & $\begin{array}{r}86 \\
82 \\
77\end{array}$ & $\begin{array}{l}100 \\
100 \\
100\end{array}$ & $\begin{array}{l}115 \\
132 \\
137\end{array}$ & $\begin{array}{l}133 \\
171 \\
203\end{array}$ \\
\hline $\begin{array}{l}\text { 2. 産業活動関連 } \\
\text { 財・サービス }\end{array}$ & $\begin{array}{l}\text { A. 産鄴基盤財 } \\
\text { B. 産業活動関連サービス } \\
\text { C. 素材, 弚の他 }\end{array}$ & $\begin{array}{l}63 \\
61 \\
81\end{array}$ & $\begin{array}{l}100 \\
100 \\
100\end{array}$ & $\begin{array}{l}133 \\
167 \\
104\end{array}$ & $\begin{array}{l}188 \\
266 \\
116\end{array}$ \\
\hline $\begin{array}{l}3 \text { ・岀用財・サー } \\
\text { ビス }\end{array}$ & $\begin{array}{l}\text { A. 住宅を除く建設 } \\
\text { B. ネットワークエネルキー }\end{array}$ & $\begin{array}{l}70 \\
76\end{array}$ & $\begin{array}{l}100 \\
100\end{array}$ & $\begin{array}{l}150 \\
127\end{array}$ & $\begin{array}{l}114 \\
163 \\
\end{array}$ \\
\hline \multicolumn{2}{|r|}{ 合 計 } & 77 & 100 & 126 & 158 \\
\hline
\end{tabular}

構成比

\begin{tabular}{|c|c|c|c|c|c|}
\hline \multicolumn{2}{|r|}{ 年 } & 1985 & 1992 & 2000 & 2010 \\
\hline $\begin{array}{l}\text { I. 家計関連財・ } \\
\text { サービス }\end{array}$ & $\begin{array}{l}\text { A. 基礎的消費（衣・食・住） } \\
\text { B. 生活向上消費 } \\
\text { C. 家計投資（住宅建設） }\end{array}$ & $\begin{array}{r}11.8 \% \\
21.1 \% \\
2.3 \%\end{array}$ & $\begin{array}{r}10.5 \% \\
19.7 \% \\
2.3 \%\end{array}$ & $\begin{array}{r}9.5 \% \\
20.5 \% \\
2.5 \%\end{array}$ & $\begin{array}{r}8.9 \% \\
21.2 \% \\
3.0 \%\end{array}$ \\
\hline $\begin{array}{l}\text { 2. 産業活動関連 } \\
\text { 財・サービス }\end{array}$ & $\begin{array}{l}\text { A. 産業基盤財 } \\
\text { B. 産業活動関連サービス } \\
\text { C.素材，その他 }\end{array}$ & $\begin{array}{r}8.3 \% \\
5.0 \% \\
22.4 \%\end{array}$ & $\begin{array}{r}10.1 \% \\
6.3 \% \\
21.3 \%\end{array}$ & $\begin{array}{r}10.7 \% \\
8.3 \% \\
17.5 \%\end{array}$ & $\begin{array}{l}12.0 \% \\
10.5 \% \\
15.6 \%\end{array}$ \\
\hline $\begin{array}{l}\text { 3. 両用財・サー } \\
\text { ビス }\end{array}$ & $\begin{array}{l}\text { A. 住宅を除く建設 } \\
\text { B. ネットワークエネー }\end{array}$ & $\begin{array}{r}5.6 \% \\
23.5 \% \\
\end{array}$ & $\begin{array}{r}6.1 \% \\
23.8 \% \\
\end{array}$ & $\begin{array}{r}7.2 \% \\
23.8 \% \\
\end{array}$ & $\begin{array}{r}4.4 \% \\
24.4 \% \\
\end{array}$ \\
\hline \multicolumn{2}{|r|}{ 合 計 } & $100.0 \%$ & $100.0 \%$ & $100.0 \%$ & $100.0 \%$ \\
\hline
\end{tabular}

注：新たな産業分類の内訳

1. 家計関連財・サービス

A. 基礎的消費……食料品，繊維，不動産（うち「住宅賃貸）

B 生活向上消費……輸送機械(「トラック・バス「炎の他の輸送機械をを除く)、䨘気機械 (うち「民生用電気・電子機械」)、精密機械(「との他の精密機械」を除く), その他の製 造業(「プラスティック製品」,「ゴム製品」を除く), 教育・医療・公共( 研究」を除く), 対個人サービス, 建設(うち「住宅補修」), [機械産業のうち部品は全て除く]

C. 家 計 投 資……建設(うち「住宅」)

2. 産業活動関連財・サードス

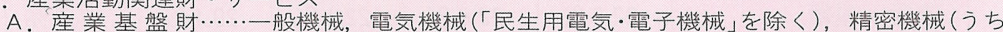
「先の他の精密機械」), 一般機械の部品, 電気機械の部品, 精密機械の部品

B. 産業活動関連サービス……不動産 (「住宅貨貸」を除く), 教育・医療・公共 (うち「研究」), 対事業所サービス

C. 素材·その他……農林水産業，鉱業，パルプ・紙，化学，窝業土石製品，鉄鋼，非鉄金 属，金属製品，その他の製造業(うち「プラスティック製品」,「ゴム製品」），輸送機械 (うち「トラック・バス」,「午他の輸送機械」), 輸送機械の部品, 弚の他

3. 画用財・サービス

A. 住宅を除く建設……建設(「住宅」、「住宅補修」を除く)

B.ネットワークエネルギー……石油・石炭製品, 電力・ガス・熱供給, 水道・廃妄物処理, 金融・保険, 卸売・小売，運輸，通信・放送 


\begin{tabular}{|c|c|c|c|c|c|}
\hline \multicolumn{6}{|c|}{ 表 4 就業構造の展望 } \\
\hline \multicolumn{4}{|l|}{ 就業者数 } & \multicolumn{2}{|c|}{ (单位：万人) } \\
\hline 年 & 1980 & 1985 & 1992 & 2000 & 2010 \\
\hline 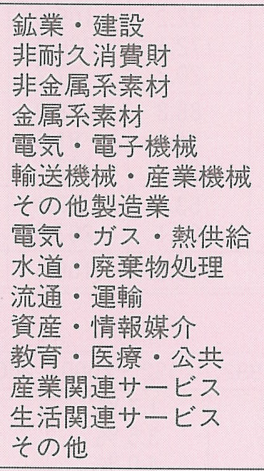 & $\begin{array}{r}591 \\
348 \\
165 \\
188 \\
148 \\
327 \\
279 \\
21 \\
36 \\
1,314 \\
276 \\
674 \\
178 \\
619 \\
746 \\
\end{array}$ & $\begin{array}{r}589 \\
362 \\
140 \\
164 \\
200 \\
333 \\
251 \\
22 \\
40 \\
1,372 \\
322 \\
736 \\
240 \\
640 \\
656 \\
\end{array}$ & $\begin{array}{r}681 \\
380 \\
157 \\
176 \\
253 \\
362 \\
267 \\
23 \\
42 \\
1,444 \\
400 \\
802 \\
387 \\
685 \\
487 \\
\end{array}$ & $\begin{array}{r}751 \\
349 \\
149 \\
162 \\
261 \\
345 \\
265 \\
23 \\
45 \\
1,405 \\
424 \\
893 \\
620 \\
848 \\
452 \\
\end{array}$ & $\begin{array}{r}590 \\
340 \\
146 \\
148 \\
255 \\
354 \\
251 \\
24 \\
49 \\
1,307 \\
437 \\
939 \\
894 \\
983 \\
265 \\
\end{array}$ \\
\hline 合 計 & 5,908 & 6,067 & 6,546 & 6,991 & 6,984 \\
\hline \multicolumn{6}{|c|}{ 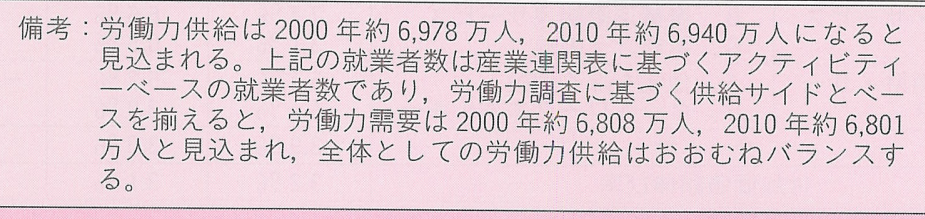 } \\
\hline \multicolumn{6}{|c|}{ 年平均伸び率 } \\
\hline 年 & 1985 & \multicolumn{2}{|c|}{1992} & 000 & 2010 \\
\hline 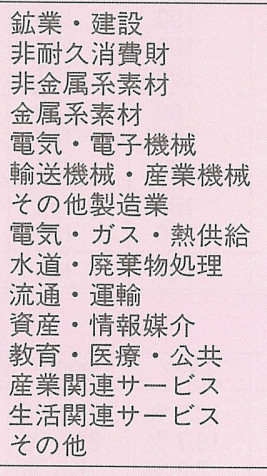 & $\begin{array}{r}-0.1 \% \\
0.8 \% \\
-3.3 \% \\
-2.6 \% \\
6.5 \% \\
0.4 \% \\
-2.1 \% \\
1.5 \% \\
2.3 \% \\
0.9 \% \\
3.2 \% \\
1.8 \% \\
6.2 \% \\
0.7 \% \\
-2.5 \% \\
\end{array}$ & $\begin{array}{r}2.1 \\
0.7 \\
1.7 \\
0.9 \\
3.4 \\
1.2 \\
0.9 \\
0.6 \\
0.6 \\
0.7 \\
3.1 \\
1.2 \\
7.1 \\
1.0 \\
-4.2 \\
\end{array}$ & & $\begin{array}{l}.2 \% \\
.1 \% \\
.7 \% \\
.0 \% \\
.4 \% \\
.6 \% \\
.1 \% \\
.2 \% \\
.8 \% \\
.3 \% \\
.7 \% \\
.4 \% \\
.1 \% \\
.7 \% \\
.9 \% \\
\end{array}$ & $\begin{array}{r}-2.4 \% \\
-0.3 \% \\
-0.2 \% \\
-0.9 \% \\
-0.2 \% \\
0.3 \% \\
-0.5 \% \\
0.2 \% \\
1.0 \% \\
-0.7 \% \\
0.3 \% \\
0.5 \% \\
3.7 \% \\
1.5 \% \\
-5.2 \% \\
\end{array}$ \\
\hline 合計 & $0.5 \%$ & 1.1 & & $.8 \%$ & $0.0 \%$ \\
\hline 構成比 & & & & & \\
\hline 年 & 1980 & 1985 & 1992 & 2000 & 2010 \\
\hline $\begin{array}{l}\text { 鉱業・建設 } \\
\text { 非耐久消費財 } \\
\text { 非金属系素材 } \\
\text { 金属系素材 } \\
\text { 電気・電子機械 } \\
\text { 輸送機械・産業機械 } \\
\text { 光の他製造業 } \\
\text { 電気・ガス・熱供給 } \\
\text { 水道・廃棄物処理 } \\
\text { 流通・運輸 } \\
\text { 資産・情報媒介 } \\
\text { 教育・医療・公共 } \\
\text { 産業闦連サービス } \\
\text { 生活関連サービス } \\
\text { 光の他 }\end{array}$ & $\begin{array}{r}10.0 \% \\
5.9 \% \\
2.8 \% \\
3.2 \% \\
2.5 \% \\
5.5 \% \\
4.7 \% \\
0.3 \% \\
0.6 \% \\
22.2 \% \\
4.7 \% \\
11.4 \% \\
3.0 \% \\
10.5 \% \\
12.6 \% \\
\end{array}$ & $\begin{array}{r}9.7 \% \\
6.0 \% \\
2.3 \% \\
2.7 \% \\
3.3 \% \\
5.5 \% \\
4.1 \% \\
0.4 \% \\
0.7 \% \\
22.6 \% \\
5.3 \% \\
12.1 \% \\
4.0 \% \\
10.5 \% \\
10.8 \% \\
\end{array}$ & $\begin{array}{r}10.4 \% \\
5.8 \% \\
2.4 \% \\
2.7 \% \\
3.9 \% \\
5.5 \% \\
4.1 \% \\
0.4 \% \\
0.6 \% \\
22.1 \% \\
6.1 \% \\
12.3 \% \\
5.9 \% \\
10.5 \% \\
7.4 \% \\
\end{array}$ & $\begin{array}{r}10.7 \% \\
5.0 \% \\
2.1 \% \\
2.3 \% \\
3.7 \% \\
4.9 \% \\
3.8 \% \\
0.3 \% \\
0.6 \% \\
20.1 \% \\
6.1 \% \\
12.8 \% \\
8.9 \% \\
12.1 \% \\
6.5 \% \\
\end{array}$ & $\begin{array}{r}8.5 \% \\
4.9 \% \\
2.1 \% \\
2.1 \% \\
3.7 \% \\
5.1 \% \\
3.6 \% \\
0.3 \% \\
0.7 \% \\
18.7 \% \\
6.3 \% \\
13.4 \% \\
12.8 \% \\
14.1 \% \\
3.8 \% \\
\end{array}$ \\
\hline 合 計 & $100.0 \%$ & $100.0 \%$ & $100.0 \%$ & $100.0 \%$ & $100.0 \%$ \\
\hline
\end{tabular}




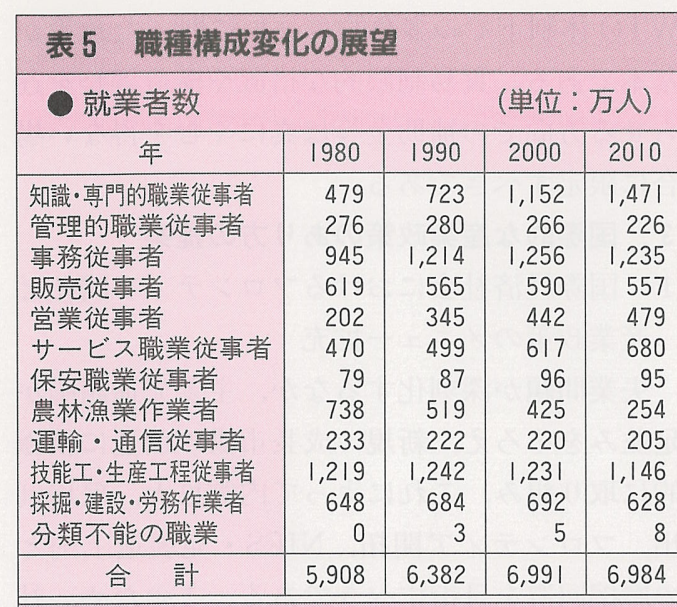

年平均伸び率

\begin{tabular}{|c|c|c|c|}
\hline 年 & $\begin{array}{l}1980 \\
-1990\end{array}$ & $\begin{array}{l}1990 \\
-2000\end{array}$ & $\begin{array}{l}2000 \\
-2010\end{array}$ \\
\hline 知識·専門的職業従事者 & $4.2 \%$ & $4.8 \%$ & $2.5 \%$ \\
\hline 管理的職業従事者 & $0.1 \%$ & $-0.5 \%$ & $-1.6 \%$ \\
\hline 事務従事者 & $2.5 \%$ & $0.3 \%$ & $-0.2 \%$ \\
\hline 販売従事者 & $-0.9 \%$ & $0.4 \%$ & $-0.6 \%$ \\
\hline 営業従事者 & $5.5 \%$ & $2.5 \%$ & $0.8 \%$ \\
\hline サービス職業従事者 & $0.6 \%$ & $2.2 \%$ & $1.0 \%$ \\
\hline 保安職業従事者 & $1.0 \%$ & $0.9 \%$ & $-0.1 \%$ \\
\hline 農林漁業作業者 & $-3.4 \%$ & $-2.0 \%$ & $-5.0 \%$ \\
\hline 運輸・通信従事者 & $-0.5 \%$ & $-0.1 \%$ & $-0.7 \%$ \\
\hline 技能工•生産工程従事者 & $0.2 \%$ & $-0.1 \%$ & $-0.7 \%$ \\
\hline 採掘・建設・労務作業者 & $0.5 \%$ & $0.1 \%$ & $-1.0 \%$ \\
\hline 分類不能の職業 & & $4.8 \%$ & $5.8 \%$ \\
\hline 合 & $0.8 \%$ & $0.9 \%$ & $0.0 \%$ \\
\hline
\end{tabular}

構成比

\begin{tabular}{|c|c|c|c|c|}
\hline 年 & 1980 & 1990 & 2000 & 2010 \\
\hline 知識・尃門的職業従事者 & $8.1 \%$ & $11.3 \%$ & $16.5 \%$ & $21.1 \%$ \\
\hline 的職業従事者 & & & & \\
\hline 㝵者 & It & 19.1 & 18. & $17.7 \%$ \\
\hline 販売 ～－ ～ & & & & \\
\hline 営業 ～～～～ & & 5.4 & & $6.9 \%$ \\
\hline 職業従事者 & 7.9 & 7.8 & 8.8 & $9.7 \%$ \\
\hline 保安職 ～～ & 1.3 & 1.4 & & $1.4 \%$ \\
\hline 漁業作業者 & 12.5 & 8.1 & 6.1 & $3.6 \%$ \\
\hline 運輸・通信従事者 & 3.9 & 3.5 & $3.2 \%$ & $2.9 \%$ \\
\hline 技能工·生産工程従事者 & $20.6 \%$ & 19.5 & $17.6 \%$ & $16.4 \%$ \\
\hline 採掘・建設・労 & 11.0 & 10.7 & 9.9 & $9.0 \%$ \\
\hline 分類不能の職 & $0.0 \%$ & $0.0 \%$ & $0.1 \%$ & $0.1 \%$ \\
\hline 計 & $100.0 \%$ & $100.0 \%$ & $100.0 \%$ & $100.0 \%$ \\
\hline
\end{tabular}

備考：

知識·専門的職業従事者……研究者, 技術者( 情報技術者 も含む)，医師，看護婦，教員，法務·会計従事者， デザイナー等

事務従事者……般事務員, 会計事務員, 兰の他事務従 事者

販売従事者……志店主, 販売店主, 飲食店主, 販売店 員, 炎の他販売従事者

営業従事者……営業員(保険を除く)，保険代理人・外交 員

サービス職業従事者……家計サービス職業従事者，理美 容等生活衛生サ一ビス職業従事者, 調理人・飲食サ 一ビス職業従事者, 炎の他サービス職業従事者
ながるものである。しかし，円高の行き過ぎや 内外価格差など経済に歪みがある場合には，本 来比較優位があるはずの産業までが海外に移転 してしまうという事態が生じうるが(しかも不 可逆的), これは問題とすべき「空洞化」であ る。歪み除去への早急な取り組みとともに，事 業活動を行う「場」としての我が国の魅力の改 善等を行わなければ，産業の「空洞化」は不可 避と考えられる。グローバルな国際的競争が加 速度的に進行するなか, 経済構造改革への取り 組みが遅れるほど復元不能な空洞が我が国経済 に拡大することになる。

\section{3 。産業構造の転換期における産業にとっての \\ 課題}

今後の我が国産業構造の転換期における産業 にとっての横断的な課題としては，(1)ハードと ソフト・サービス，開発・調達・生産・流通， 官業と民業等の間において相互連関的・相乗的

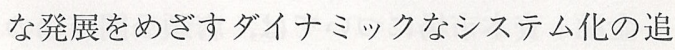
求，(2)アジアを含めた国際分業構造の精緻化， 海外調達を含めた柔軟な最適生産体制の構築 等，産業活動のグローバルな分業化の追求，(3) 非貿易財の生産性を高め, 非効率部門を効率化 することによる内外価格差縮小の追求の 3 点が ポイントになると考えられる。

\section{(2) 産業政策の新たなパラダイム}

\section{1。新たなパラダイムに立脚した産業政策の考}

\section{方}

(1)基本的な視座：1)経済構造改革を進めるなか での産業政策（経済全体の歪み是正を通じた実 質的な生活水準・豊かさの向上と産業の適正な 競争力の回復)，2）需要サイドにウエイトを移 しながら, 需要サイド・供給サイド両面を一体 としてとらえる対応 (潜在的な需要の発見と市 場の創造，結果として産業が発展)，3）グロー バルな最適分業構造の形成。

(2)政策手法の考え方：1)諸制度・規制等を所与 のものとして受け入れるのではなく，市場機能 強化のための制度整備，規制緩和，民間慣行是 正等を重視，2)社会資本整備，技術基盤整備， 
良質な人的ストックの形成等従来産業政策の手 段として十分認識されてこなかった広い意味で の基盤整備の強化，3) 各分野毎の課題に対応し た各種政策手法のシステマティックな組み合わ せ・実行の重視。

(3)政策の国際的広がり：「内外一致」の政策, 国際的な産業政策の提案・働きかけ。

\section{2.国内における政策の展開}

(1) 規制緩和・制度改革

内外価格差是正, 新規市場創出, 内外企業の 新規参入促進のため規制緩和を早期かつ重点的 に実行すべきである。

競争政策については，民間慣行を是正するた めのカルテル規制・不公正取引規制の強化等の 一方で企業のさまざまなりストラを可能にする ための合併規制の運用適正化・純粋持株会社一 律禁止規制の見直し等，「競争政策の多角的見 直し」を推進すべきである。

金融・資本市場については, 店頭公開市場の 改善，新たな投資システムの創設，社債発行・ 流通市場の育成・整備等を通じて, 新規事業に 対する円滑な資金供給, 既存企業の資金調達手 段の多様化・効率化を促すことが必要である。

労働市場については, 労使間における勤務形 態の多様化・複線化等の内部労働市場の変革と ともに, 政府における外部労働市場の整備, 幅 広い人材育成, 高齢者・女性の雇用環境整備等 のための制度改革や支持措置が必要である。

（2）社会資本整備

高齢化社会への備え, 豊かでゆとりある国民 生活の実現, 対外不均衡の是正, 新規・成長市 場の創出をはじめとする産業支持基盤の構築等 のため, 社会資本整備の拡充・前倒し, 効率 的・重点的な実施が必要である。

(3) 研究開発基盤整備

研究開発基盤の整備, 政府における基盤的研 究開発の量・質両面での抜本的強化，技術シー ズの産業活動への具体化促進等民間研究開発支 援, 国際協同研究開発の推進等が必要である。

(4) 通商政策との関連

産業政策と通商政策との関係が深まるなか,
WTO 体制下での多角的ルールに則った政策が 基本である。貿易制限的な措置や構造調整を遅 らせる方向での補助金等は真にやむを得ない場 合に限定すべきである。

\section{3 、国際的な産業政策のあり方の提案}

(1) 国際経済社会におけるフロンティア開拓と 産業政策のメニュー拡充

失業問題が深刻化するなか, 主要先進諸国が 足並みをそろえ，新規・成長市場の創造に積極 的に取り組み,これによって内需拡大, 雇用創 出, フロンティア開拓, NIES・発展途上国と の摩擦回避を目指すべきである。このため，社 会資本整備・規制緩和・能力開発等各国産業政 策のメニューの拡充が求められている。

(2) 産業政策に関する多角的ルールの拡充・強 化

自国産業の競争力強化の動きと行き過ぎの懸 念, 保護的措置の残存等の状況を踏ま之, 先端 産業育成のための貿易措置の禁止, 時限性の確 保等市場メカニズムによる構造調整の重視等産 業政策に関する多角的ルールの拡充・強化（原 則の確認，規範性の強化）に取り組むことが必 要になっている。

（3）国際的な経済活動のフィールド整備

制度のハーモナイゼーション等国際的な経済 活動のフィールド整備に積極的に取り組むべき である。「貿易と労働基準」の問題については, 先進国における自由貿易に基づく発展途上国へ の市場提供, 発展途上国における労働条件向上 への主体的取り組みを基本とすべきである。

\section{3. 展望作業の進め方について}

\section{(1) 産業ごとの生産額の推計}

今回の産業構造の展望にあたっては, 標準産 業分類を基本として作業の便宜を考慮して独自 に作成した産業分類に基づいて作業を行った。 主要なマクロ経済指標については 93 年 11 月に 本委員会が取りまとめた「中間提言」において 示された数值を前提とするとともに,「中間提 言」がその必要性を訴えた(1)社会資本整備の拡 
充・前倒し実施を柱とするマクロ構造調整，(2) 規制緩和・民間慣行是正とその結果としての内 外価格差是正を柱とするミクロ経済改革，(3) ストラ円滑化・新規産業の展開支援等のための 産業構造政策を三位一体とした政策が実行され た場合を想定している。

まず，仮定された経済指標及び個々の産業に 関係の深いさまざまな指標 (例：人口, 普及率 等)を用いて, 国内外の市場構造の変化や技術 革新の成果とその効果を踏まえながら, 既存の 産業分類ごとに最終需要額の推計を行ったに の作業に当たっては新規産業の展開については 考虑していない)。中間財としての性格を有す る産業については，その産業に関係の深い産業 分類ごとの最終需要額の推計を用いて, 最終需 要額の推計と同様の手法により産業分類ごとの 生産額の推計を行った。

新規・成長産業については, 社会ニーズの変 化や技術革新の成果が新たな製品やサービスに 結実することを考虑し，個々の商品ごとに将来 の国内市場規模の推計を行うとともに，その展 開が既存の産業の需要額に与える影響—商品 の代替効果(例えばマルチメディアの発達が既 存の通信産業に与える影響) 及び他の商品の誘 発効果(例えばマルチメディアの発達により誘 発される通信網整備のための建設需要) 一の 推計を行った。

以上の既存産業と新規・成長産業の展望を合 体することにより産業分類ごとの生産額の推計 を行うとともに，各産業ごとの推計值を個々の 産業の推計作業にフィードバックし前述の作業 を繰り返し行うことにより, 産業間の相互依存 関係の調整を行った。

\section{(2) 産業ごとの投入構造の推計}

生産額の推計作業に併せて, 産業連関表を用 いて産業分類ごとに投入構造の変化の推計を行 い，産業分類ごとの生産額と投入係数を用い て, 産業間の相互依存関係の調整や粗付加価值 額と最終需要額の整合性の調整を行った。生産 額の推計においても技術革新による投入構造の
変化を折り込んではいるが，産業全体としての バランスのチェックまでは行えないことから別 途本作業により行ったものである。

産業分類ごとの投入係数の推計は，まず過去 の産業連関表を用いてそのトレンド変化を機械 的に計算した後に，個々の産業分類ごとの個別 要因を加味して行った。産業間の調整は, 推計 した生産額と投入係数を用いて産業連関表を投 入側から作成し, 生産額の推計過程で推計した 産業分類ごとの最終需要額を産出側に代入し た。当然，投入側と産出側の生産額が異なるた め, 差の大きい産業分類から順に, 産業連関表 上の項目ごとに差の生じた原因を推定し, 当該 産業や他の関連する産業の生産額や投入係数等 の調整を行う作業を繰り返し, 最終的な調整は 数学的な収束計算によって行った。

前述した報告書の概要で述べた産業構造の展 望結果は,このようにして推計された 2000 年 及び 2010 年の産業連関表を, より大きな産業 分類ごとに合算したものである。

\section{(3) 就業構造及び職種構成の推計}

就業構造の展望は, 産業構造の展望過程で推 計した産業分類ごとや，新規・成長産業ごとの 労働生産性の上昇率と産業構造の展望結果を基 にして推計したものである。

職種構成の展望は, 産業分類ごとの職種構成 の変化の推計を投入構造の変化の推計と同様の 手法により別途行い, 産業構造の展望結果と合 わせて推計したものである。

\section{3. 今後の課題}

今回の展望作業は, 各産業の担当者が推計し た展望の積み上げを基本とし，各担当者は当該 産業と平素より関わっている者としたが，第 3 次産業について知見を有している者が少なく, デー夕や文献も少ないため, 第 2 次産業ほどの 細かさで担当者を配置することができず，第 3 次産業の産業分類は第 2 次産業に比べ粗いもの となっている。今後, 我が国経済におけるサー 
ビス業の重要性はますます高まると考えられる ことから，第 3 次産業に関する知見を平素より 蓄えておくことが重要であると考えている。

また，今回展望を行った産業の中には，市場 が成熟化したため需要が周期的に大きく変化 し，それに合わせて生産も変化せざるをえない と考えられる産業が増えてきており，産業の将 来展望を行う際に, より動的に産業をとらえな ければ本質をつかめなくなってきている。展望 作業全体を動的に行うことは困難であるが, 部
分的に動的な変化を取り入れ，分かりやすく表 現する手法を開発することが必要になってきて いると思われる。

なお，今回の展望作業は準備期間も含め約 6 カ月という短期間で行われたため，細部におい てはデータベースの不統一や前提条件の不徹底 が存在する。定量的な展望作業は夕イミングが 重要であるため, 大宗に影響のない問題は敢え て取り上げず作業を進めたことをご容赦願いた w。 